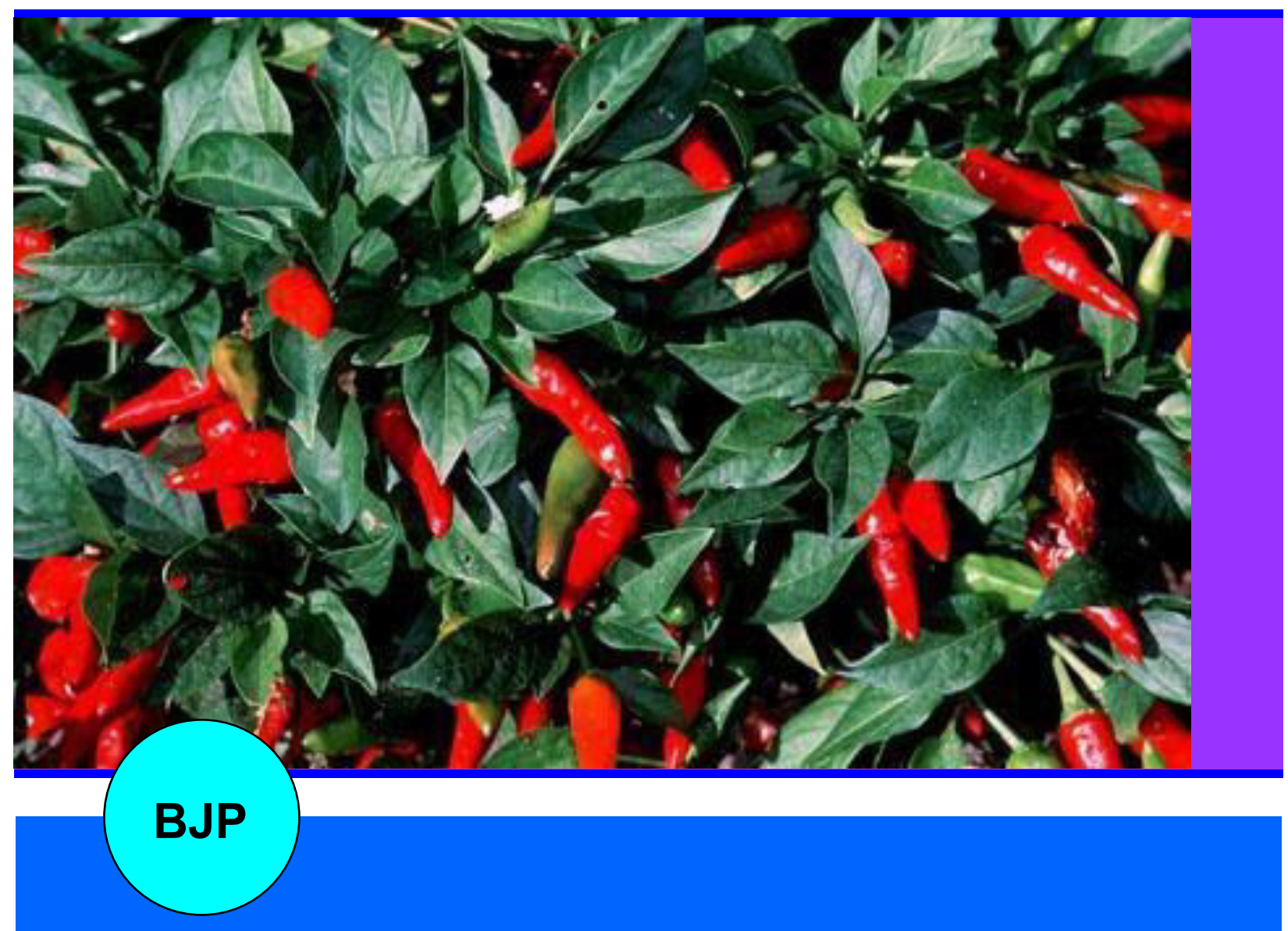

Bangladesh Journal of Pharmacology

Research Article

Pharmacological validation of anxioIytic, muscle relaxant and sedative like activities of Capsicum annuum in animal model 


\title{
Pharmacological validation of the anxiolytic, muscle relaxant and sedative like activities of Capsicum annuum in animal model
}

\author{
Muhammad Jawad', Haroon Khan', Samreen Pervaiz², Saud S. Bawazeer³, \\ Tareq Abu-Izneid3, Muhammad Saeed ${ }^{2}$ and Mohammad Amjad Kamal4
}

\begin{abstract}
${ }^{1}$ Department of Pharmacy, Abdul Wali Khan University Mardan 23200, Mardan, Pakistan; ${ }^{2}$ Department of Pharmacy, University of Peshawar 25200, Peshawar, Pakistan; ${ }^{3}$ Department of Pharmaceutical Sciences, Faculty of Pharmacy Umm Al-Qura University, Makkah, P.O. Box 42, Saudi Arabia; ${ }^{4}$ King Fahd Medical Research Center, King Abdulaziz University, Jeddah, Saudi Arabia.
\end{abstract}

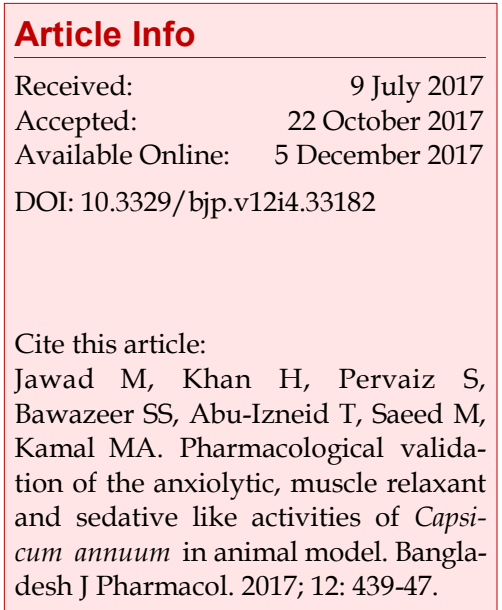

\begin{abstract}
The current study deals with anxiolytic, muscle relaxant and sedative like activities of Capsicum annuum in animal models. The crude extract was found safe in acute behavior and toxicity studies. However, the $n$-hexane fraction caused severe acute toxicity. Pretreatment of crude extract and $n$-hexane fraction elicited marked dose-dependent antianxiety-like effects in elevated plus-maze and dark and light models. The results showed significant $(\mathrm{p}<$ $0.05)$ antianxiety-like effects of crude extract while highly significant $(p<$ 0.001 ) for $n$-hexane fraction. Similarly, an effect on muscle coordination was tested in traction model, where both crude extract and $n$-hexane fraction evoked marked dose-dependent activity. The effect of thiopental-induced sleep test of crude extract and $n$-hexane fraction was highly significant $(\mathrm{p}<$ 0.001). All together, the results revealed potent anxiolytic, muscle relaxant and sedative like activities of $C$. annuum in animal models and the pharmacologically active constituents are mostly non-polar in nature.
\end{abstract}

\section{Introduction}

Global statistics revealed that approximately 450 million people throughout the world suffer from the mental illness or behavioral disorders, which account for $12.3 \%$ of the global burden of disease. It is supposed to be reached $15 \%$ by the year 2020 . Amongst the many mental illnesses and behavioral disorders, anxiety and depression are the two most prevailing psychiatric disorders (He et al., 2015). Anxiety, a state of uncontrollable fear, is denoted by a hyperactive sympathetic nervous system, psychomotor tension, perturbation and vigilance syndromes (Mansouri et al., 2014). Worldwide, anxiety disorders constitute the most common forms of psycho-pathology (Hellian-Ibarrola et al., 2006) nearly inflicting almost one-eighth of the total population globally (Komaki et al., 2014).
Benzodiazepines are the most common class of drugs prescribed in anxiety and they continue to be prescribed for the ailment as such (Lader and Morton, 1991). Although as a class benzodiazepines are quite effective, acting rapidly and exhibiting good tolerability. But along with these advantages, there are certain issues that are clinically important to consider, such as, may cause dependence, disruption can lead to rebound anxiety and also memory impairment (Chouinard, 2004). This has compelled researchers to evaluate new compounds specially plant-based drugs having less undesirable effects (Tiwari et al., 2014). Capsicum annuum commonly known as pepper belongs to Solanaceae family. Worldwide, it is one of the most highly consumed season-free vegetables (Kim et al., 2014). Epidemiological facts indicated the useful effects of food/dietary anti-oxidant compounds in the 
prevention of a number of disease states, which includes cancer, neurodegenerative disorders and cardiovascular disease (Hollman, 1999; Harborne and Williams, 2000; Ferrari and Torres, 2003).

C. annuum is reported to be an excellent source of polyphenols, particularly flavonoids such as quercetin, myricetin, luteolin, and capsaicin (Lee and Villalon, 1995; Miean and Mohamed, 2001; Chen and Hwa, 2013), caffeic, coumaric and 3,4-dimethoxy cinnamic acid glucosides (Mattila and Hellstorm, 2007). In addition to that, in pepper leaves some other flavonoids were also identified, apigenin and its analogue apigenin 7piofuranosyl [1 $\rightarrow 2$ ] glucopyranoside (Choi et al., 2007). Health promoting phytochemical constituents like quercetin, myricetin, apigenin, luteolin, are commonly exist in C. annuum. These show antidepressant and anxiolytic activities in the previous studies (Kumar and Sharma, 2006; Aguirre-Hernandez et al., 2010; Ishisaka et al., 2011; Impellizzeri et al., 2013). C. annuum is also one of the constituents in a well-known poly-herbal product Xtend ${ }^{\mathrm{R}}$ which is widely used in the Egypt for the antidiabetic, antianxiety and antidepressant effects (El-Ashmawy et al., 2014).

Based on its traditional uses and its potential phytochemical composition, the aims of the present study were to investigate the anxiolytic like effects of the methanolic extract and the $n$-hexane fraction of $C$. annuum in elevated plus-maze (EPM) and light and dark (LD) model behavioral test for anxiolytic drug. Additionally, the possible sedative and muscle relaxant like effects of the C. annuum extracts were also evaluated in vivo.

\section{Materials and Methods}

\section{Drugs and chemicals}

Diazepam (valium injection $10 \mathrm{mg} / 2 \mathrm{~mL}$ manufactured by Martin Dow), thiopental sodium, Tween 80, methanol and $n$-hexane were purchased from the local chemical market.

\section{Animals}

Healthy (male) albino mice having a weight of 25-35 g were purchased the National Institute of Health Islamabad, Pakistan. Prior to the experiments, all mice were kept in cages having control temperature $22 \pm 1^{\circ} \mathrm{C}$ with light and dark cycle of 12 hours each. Food pellets and water were supplied regularly. Mice were grouped so that each group contained 6 animals. All experimental works were performed between 9:00 a.m. and 2:00 p.m. Pharmaceutical Ethics Committee of the Pharmacy Department at Peshawar University approved the study.

\section{Collection of the plant material}

Mature fruits of C. annuum $(8 \mathrm{~kg})$ were collected from the District Swabi. The plant was identified as C. annuum in the Department of Botany, University of Islamia, Peshawar, KPK, Pakistan. For future reference, a specimen having voucher number 102 was kept in their herbarium.

After cleaning the fruits, it was dried for 15 days and then crushed into powder, having a weight of $1,800 \mathrm{~g}$.

\section{Preparation of extract}

After harvesting, the fruit of C. annuum $(8 \mathrm{~kg})$ was dried in the sun. The maceration process was used. The fruit powder was macerated for 14 days with methanol at $25^{\circ} \mathrm{C}$ and with occasional shaking the methanolic extracts after filtration were concentrated in vacuum, resulting in a crude extract. Half of the crude extract (900 g) was dissolved in distilled water and further fractionated with $n$-hexane. The resultant fraction was filtered and dried yielding about $63 \mathrm{~g}$ (7\%) of crude extract.

\section{Acute toxicity test}

For any possible toxicity, C. annuum was passed from the acute toxicity test and confirm its safety. Mice were divided into groups and treated with different doses of crude extract $(500,1000$ and $1500 \mathrm{mg} / \mathrm{kg})$ and $n$-hexane fraction of $C$. annuum, while the control group received saline and Tween $80(10 \mathrm{~mL} / \mathrm{kg})$. For any gross effects, all experimental groups were observed during the first four hours of the experiment. The mortality was observed if any after 24 hours (Khan et al., 2010).

\section{Elevated plus maze (EPM) model}

The EPM test was used for the evaluation of anxiety like effect in the animal model (Pellow and File, 1986; Nogueira and Silvia, 1996). Briefly, The EPM model was designed with two open arms $(30 \mathrm{~cm} \times 5 \mathrm{~cm})$ and two closed arms $(30 \mathrm{~cm}$ and $\times 5 \mathrm{~cm} \times 15 \mathrm{~cm})$. These arms were arranged in such a way that the closed arms were located directly opposite to each other. The maze consists of the central square $(5 \mathrm{~cm} \times 5 \mathrm{~cm})$ due to which the model seems like a plus sign. The EPM was $50 \mathrm{~cm}$ above the floor. The floor and the walls of all arms were painted black and wooden. The mice were divided into different groups. Each group consisted of 6 animals. The normal saline and $2.5 \%$ Tween $80(10 \mathrm{~mL} / \mathrm{kg})$ were administered to all animals in the control group and diazepam $(1 \mathrm{mg} / \mathrm{kg})$ to the standard group. Three groups of animals were treated with $C$. annuum crude extract at a dose of $(2.5,5$ and $10 \mathrm{mg} / \mathrm{kg})$ and $n$-hexane fraction of C. annuum at a dose of $2.5,5$ or $10 \mathrm{mg} / \mathrm{kg}$ were administered to animals in the next three groups. During experiment, the mouse was placed one by one on the center and face of the mouse towards the open arm. For the analysis of experimental work, the number of entries and time spent on the apparatus were recorded over a period of $5 \mathrm{~min}$ (Gupta et al., 2013).

\section{Light and dark (LD) model}

This LD model was elaborated (Crawley and Goodwin, 
1980). The LD apparatus consisted of a box with compartments having dimensions $(25 \mathrm{~cm} \times 33 \mathrm{~cm} \times 24$ $\mathrm{cm})$. The compartments were connected each other by an opening $(7 \mathrm{~cm} \times 7 \mathrm{~cm})$. Through this opening, the mouse was allowed to move from one compartment to the other. One of the compartments had $100 \mathrm{~W}$ bulb which emit visible light placed in at a height of $30 \mathrm{~cm}$ while the other compartment remained dark. Mice were divided into different groups. Each group consisted of 6 animals. The normal saline and $2.5 \%$ Tween $80(10 \mathrm{~mL} /$ $\mathrm{kg}$ ) were administered to all the animals in the control group and diazepam $(1 \mathrm{mg} / \mathrm{kg})$ to the standard group. Three groups of animals were treated with $C$. annuum crude extract at a dose of $2.5,5$ or $10 \mathrm{mg} / \mathrm{kg}$. The $n$ hexane fraction of C. annuum at a dose of $2.5,5$ or 10 $\mathrm{mg} / \mathrm{kg}$ was administered to animals in the next three groups. The transition of mice between the light and dark compartments and the time spent by them in it was recorded for a period of $5 \mathrm{~min}$ immediately just after the mouse stepped in the dark compartment (Gupta et al., 2013).

\section{Muscle relaxant activity (Traction test)}

In this procedure model, the traction test was designed as two supports placed. In these supports, a rubbercoated metal wire was crimped at a height of $60 \mathrm{~cm}$. Mice were divided into different groups. Each group consists of 6 animals. These groups were treated with diazepam $(1 \mathrm{mg} / \mathrm{kg})$, normal saline and $2.5 \%$ Tween 80 $(10 \mathrm{~mL} / \mathrm{kg})$ and C. anuum crude $(50,100$ and $200 \mathrm{mg} /$ $\mathrm{kg}$ ) and $n$-hexane fraction (5, 10 and $15 \mathrm{mg} / \mathrm{kg}$ ). After $30 \mathrm{~min}$ of administration of the test and standard doses, the mice were exposed to the traction test. Normally mice grasp the wire with one hind foot within 5 sec. Failure to grasp the wire shows muscle relaxant activity of the test compound (Muhammad et al., 2013, Rauf et al., 2013).

\section{Thiopental-induced sleep test in mice}

The animals were divided into groups $(n=6)$. The control group was treated with normal saline and $2.5 \%$ Tween $80(10 \mathrm{~mL} / \mathrm{kg})$. The standard group was treated with diazepam $(1 \mathrm{mg} / \mathrm{kg})$. The next three groups were treated with the crude extract of $C$. annuum at a dose of 50,100 or $200 \mathrm{mg} / \mathrm{kg}$ i.p. and remaining three groups were treated with $n$-hexane fraction of $C$. annuum at a dose of $2.5,5$ or $10 \mathrm{mg} / \mathrm{kg}$. Thirty minutes after the administration of test doses, thiopental sodium $30 \mathrm{mg} /$ $\mathrm{kg}$ (i.p.) was injected intraperitonially. The onset of sleep and the duration of sleep were observed in each animal. The duration of time between the loss and regaining of righting reflex were considered sleeping time (Dandiya, 1959, Rauf et al., 2016).

\section{Statistical analysis}

The results obtained from all the experiments were expressed as the mean \pm S.E.M. All these results were analyzed with the help of One-way Analysis of Variance (ANOVA).

\section{Results}

\section{Effect of acute toxicity test}

The effect of acute toxicity test of the crude extract and $n$-hexane fraction of C. annuumis is present in Table I. Following intraperitoneal administration of C. annuum crude extract at the following doses 500, 1000 and 1500 $\mathrm{mg} / \mathrm{kg}$, there showed no toxicity and also no significant changes in behavior were demonstrated. The groups tested with $n$-hexane fraction of $C$. annuum caused bleeding from the mouth of the mouse and thus lead to death within $5 \mathrm{~min}$, of three animals at a dose of $15 \mathrm{mg} /$ $\mathrm{kg}$ and all the mice died on $20 \mathrm{mg} / \mathrm{kg}$.

\section{Table I}

Effect of crude and hexane fraction of $C$. annum in acute toxicity test

\begin{tabular}{|c|c|c|c|c|c|c|c|}
\hline & Control & \multicolumn{3}{|c|}{ Crude extract $(\mathrm{mg} / \mathrm{kg})$} & \multicolumn{3}{|c|}{$n$-hexane fraction $(\mathrm{mg} / \mathrm{kg})$} \\
\hline Observation & 10 & 500 & 1000 & 1500 & 10 & 15 & 20 \\
\hline Alertness & + & + & + & + & + & + & - \\
\hline Awareness & + & + & + & + & + & + & - \\
\hline Touch response & + & + & + & + & + & + & - \\
\hline Sound response & + & + & + & + & + & + & - \\
\hline Temperature & - & - & - & - & - & - & - \\
\hline Food intake & + & + & + & + & + & + & - \\
\hline Sedation & - & - & + & + & + & + & + \\
\hline Drowsiness & - & - & - & + & - & + & + \\
\hline Diarrhea & - & - & - & - & - & - & - \\
\hline Survived & All & All & All & All & All & 3 & 6 \\
\hline Death & - & & - & - & $20 \%$ & $50 \%$ & $100 \%$ \\
\hline $\mathrm{LD}_{50}$ & & & & & & $15 \mathrm{mg}$ & \\
\hline
\end{tabular}




\section{Effect in EPM model}

The effect of elevated plus maze model test of the crude extract and $n$-hexane fraction of $C$. annuum is present in Figure 1 and Figure 2 respectively. The administration of diazepam $(1 \mathrm{mg} / \mathrm{kg})$ significantly increased the entries into the open arms and also time spent in there. The pre-treatment of the crude extract $(50,100,200 \mathrm{mg} /$ $\mathrm{kg}$ ) produced a significant $(\mathrm{p}<0.05)$ reduction in the time spent in the closed arm. However, the $n$-hexane fraction was comparatively potent and evoked highly significant $(p<0.001)$ effect at the $2.5,5$, and $10 \mathrm{mg} / \mathrm{kg}$ treated mice by increasing in the number entries to open arms and also time spent in the open arms. Time spent in the closed arms were also markedly decreased.

\section{Effect in LD model}

The effect of light and dark test of the crude extract (Figure 3 ) and $n$-hexane fraction (Figure 4 ) of C. annuum is present in Figures. The crude extract of $C$. annuum at the dose of 100 and $200 \mathrm{mg} / \mathrm{kg}$ produced a significant $(p<0.01)$ increase in the time spent on the illuminated box of the LD apparatus compared to the control group. At these doses, it also produced a significant $(\mathrm{p}<0.001)$ increase in the transitions of mice to the light side. Those groups tested with the $n$-hexane fraction of $C$. annuum (5 mg/ $\mathrm{kg}$ ) showed a significant increase in the time spent on illuminated side as well as the number of transitions were also increased extremely significantly.

\section{Effect of traction test}

The effect of traction test of the crude extract and $n$ hexane fraction of $C$. annuum is present in Table II. The crude extract of C. annuum at 50 and $100 \mathrm{mg} / \mathrm{kg}$ did not show any significant muscle relaxant effect ( $0 \%$ failure). However, the crude extract after the administration of $200 \mathrm{mg} / \mathrm{kg}$ caused a significant increase in the reestablishment time at that dose $37 \%$ mice fail to made reestablishment within $5 \mathrm{sec}$. The groups tested with the $n$-hexane fraction at dose $2.5 \mathrm{mg} / \mathrm{kg}$ showed the normal reestablishment time while at 5 and $10 \mathrm{mg} / \mathrm{kg}$ the reestablishment time increased in resulting in $37 \%$ and $87 \%$ failure respectively of mice.

\section{Effect in thiopental-induced sleep in mice}

The effect of thiopental-induced sleep test of the crude extract and $n$-hexane fraction of $C$. annuum is presented in Figure 5. The group treated with the crude extract at $200 \mathrm{mg} / \mathrm{kg}$ showed significant $(\mathrm{p}<0.01)$ decrease in the onset time and significantly $(\mathrm{p}<0.05)$ increased the duration of sleep. The group tested with $n$-hexane fraction at a dose of $10 \mathrm{mg} / \mathrm{kg}$ elicited significantly $(p<0.001)$ decrease in the onset of action and significantly increased the duration of sleep.

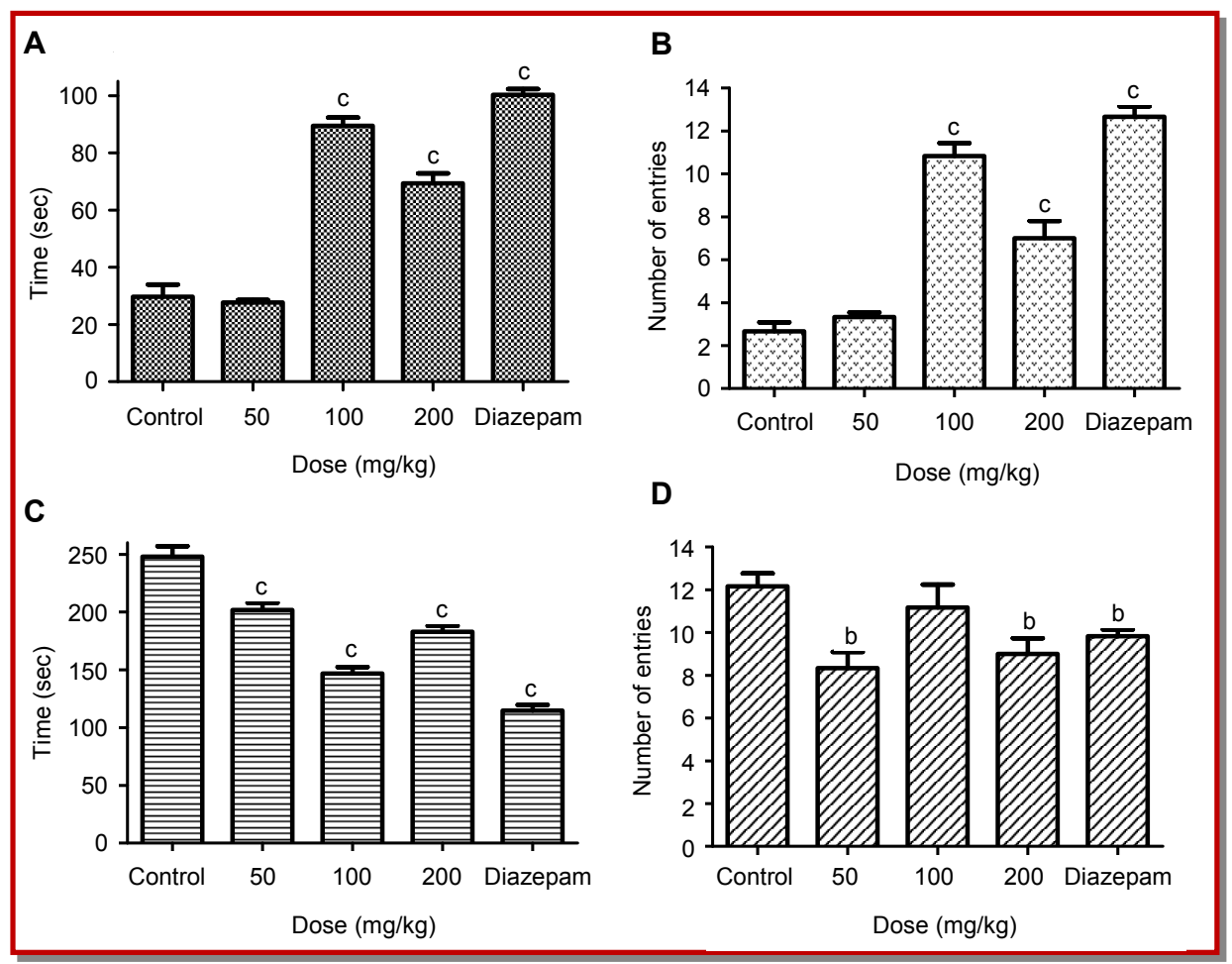

Figure 1: Effect of crude extract of C. annum at test doses in elevated plus-maze model. Time spent in open arm (A), Number of entries to open arm (B), Time spent in close arm (C), Number of entries to closed arm (D). Control (Saline and tween $802.5 \%$ ), $50,100,200 \mathrm{mg} / \mathrm{kg}$ (crude extract of C. annum), and Diazepam $1 \mathrm{mg}$. All values are expressed as mean $\pm \mathrm{SEM}, \mathrm{n}=6 .,{ }^{\mathrm{a}}<0.05$, ${ }^{b} \mathrm{p}<0.01, \mathrm{c} p<0.001$ 


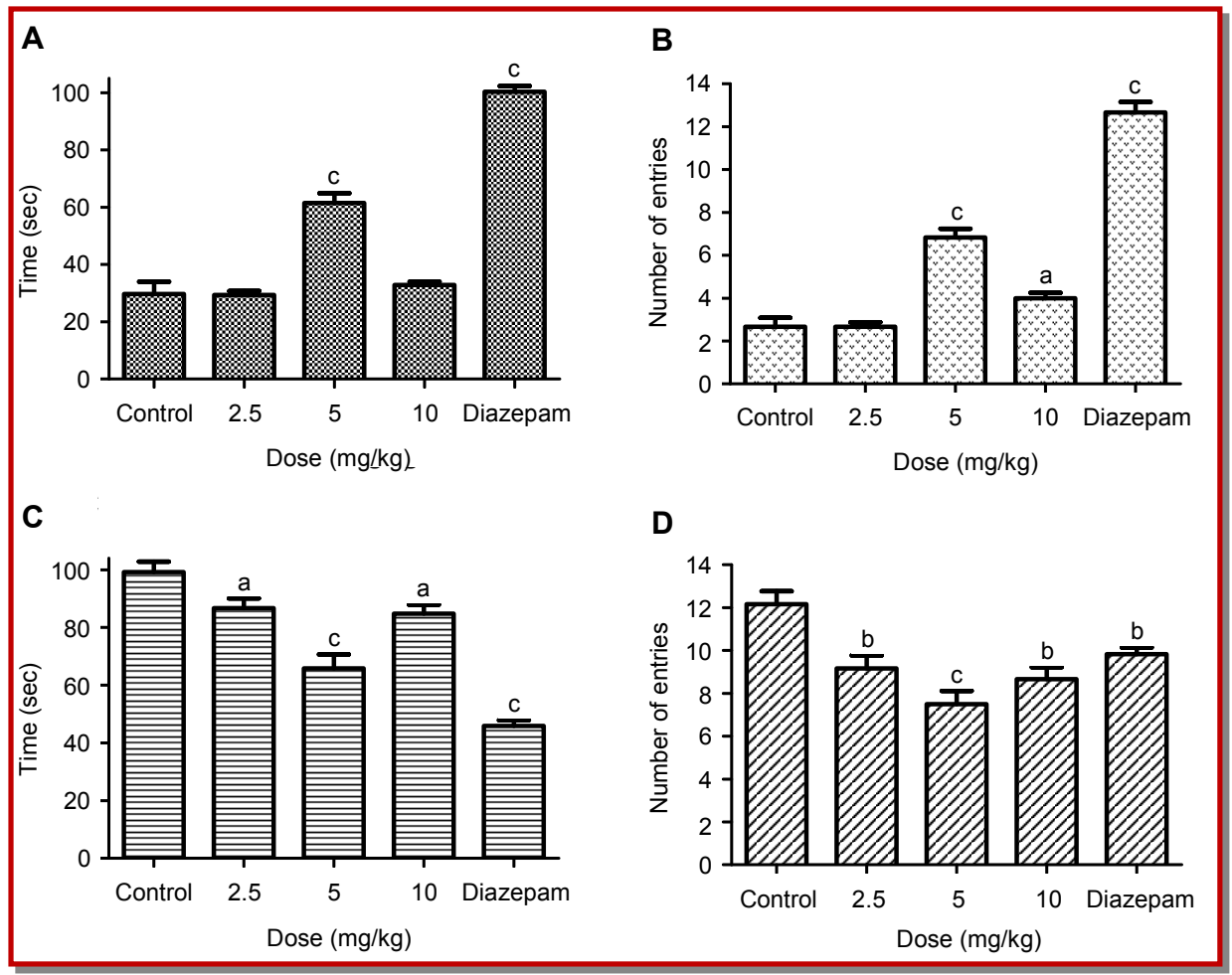

Figure 2: Effect of $n$-hexane fraction of C. annum, at test doses in elevated plus maze model. Time spent in open arm (A), Number of entries to open arm (B), Time spent in close arm (C), Number of entries to closed arm (D). Control (Saline and Tween $802.5 \%$ ), $2.5,5,10 \mathrm{mg} / \mathrm{kg}$ ( $n$-hexane fraction of $C$. annum), and diazepam $1 \mathrm{mg}$. All values are expressed as mean $\pm \mathrm{SEM} ; \mathrm{n}=6$; ${ }^{\mathrm{a}} \mathrm{p}<0.05$, ${ }^{b} \mathrm{p}<0.01, \mathrm{cp}<0.001$

\section{Table II}

\begin{tabular}{|c|c|c|c|}
\hline \multirow{2}{*}{\multicolumn{4}{|c|}{$\begin{array}{r}\text { Effect of crude and hexane fract } \\
\text { traction test } \\
\text { Traction test }\end{array}$}} \\
\hline & \\
\hline SL. No. & Treatment & Dose & $\%$ Failure \\
\hline 1 & Normal saline & $10 \mathrm{~mL} / \mathrm{kg}$ & $0.0 \%$ \\
\hline \multirow[t]{2}{*}{2} & \multirow[t]{2}{*}{ Diazepam } & $1 \mathrm{mg} / \mathrm{kg}$ & $75^{c}$ \\
\hline & & $2 \mathrm{mg} / \mathrm{kg}$ & $100^{c}$ \\
\hline \multirow[t]{3}{*}{3} & \multirow[t]{3}{*}{ Crude extract } & $50 \mathrm{mg} / \mathrm{kg}$ & 0.0 \\
\hline & & $100 \mathrm{mg} / \mathrm{kg}$ & 0.0 \\
\hline & & $200 \mathrm{mg} / \mathrm{kg}$ & $37.5^{\mathrm{b}}$ \\
\hline \multirow[t]{3}{*}{4} & \multirow[t]{3}{*}{$n$-Hexane fraction } & $2.5 \mathrm{mg} / \mathrm{kg}$ & 0.0 \\
\hline & & $5 \mathrm{mg} / \mathrm{kg}$ & $37.5^{b}$ \\
\hline & & $10 \mathrm{mg} / \mathrm{kg}$ & $87.5^{c}$ \\
\hline
\end{tabular}

\section{Discussion}

The current study revealed marked anti-anxiety (elevated plus maze and light-dark models), muscle relaxant (traction test) and sedative (thiopental-induced sleep in mice) like effects of crude extract and $n$-hexane fraction of $C$. annuиm. However, the $n$-hexane fractions elicited actions that were highly pronounced than crude extract including its toxicity.
In acute toxicity assessment of the crude extract and $n$ hexane fraction of $C$. annuum, the acute toxicological effect was observed for $n$-hexane fraction only. Previous studies showed that hexane fraction of Capsicum fruit at $200 \mathrm{mg} / \mathrm{kg}$ cause death of all the mice (Johnson, 2007). Among the capsinoids found in the pepper capsaicin and its analogue dihydrocapsaicin are the most abundant one, these two almost comprises 80 to $90 \%$ of the total flavonoids (Wesolowska et al., 2011).

The capsaicin is very potent and toxic in nature. It was already reported that in acute oral toxicity study the capsaicin $\mathrm{LD}_{50}$ value is $118 \mathrm{mg} / \mathrm{kg}$ for oral route. Those animals which were died, their examination showed that hemorrhage of the gastric fundus occurred in them. In comparison to oral toxicity the intravenous, subcutaneous and intraperitoneal, $\mathrm{LD}_{50}$ values were lower (Johnson, 2007). The large variation in the acute toxicity of capsaicin was found which depends on the route of administration. $\mathrm{LD}_{50}$ varies from $0.56 \mathrm{mg} / \mathrm{kg}$ to $60-75$ $\mathrm{mg} / \mathrm{kg}$ (in ethanol) and $19 \mathrm{mg}(122-294) \mathrm{mg} / \mathrm{kg}$ (in dimethyl sulfoxide), following intragastric intuba-tion. Respiratory paralysis was the possible cause of death in all the mice.

The EPM is a widely used paradigm for the assessment of antianxiety like effects of test articles. Indeed, it is considered as a versatile and specifically designed method for the compounds that mediate the antianxiety 


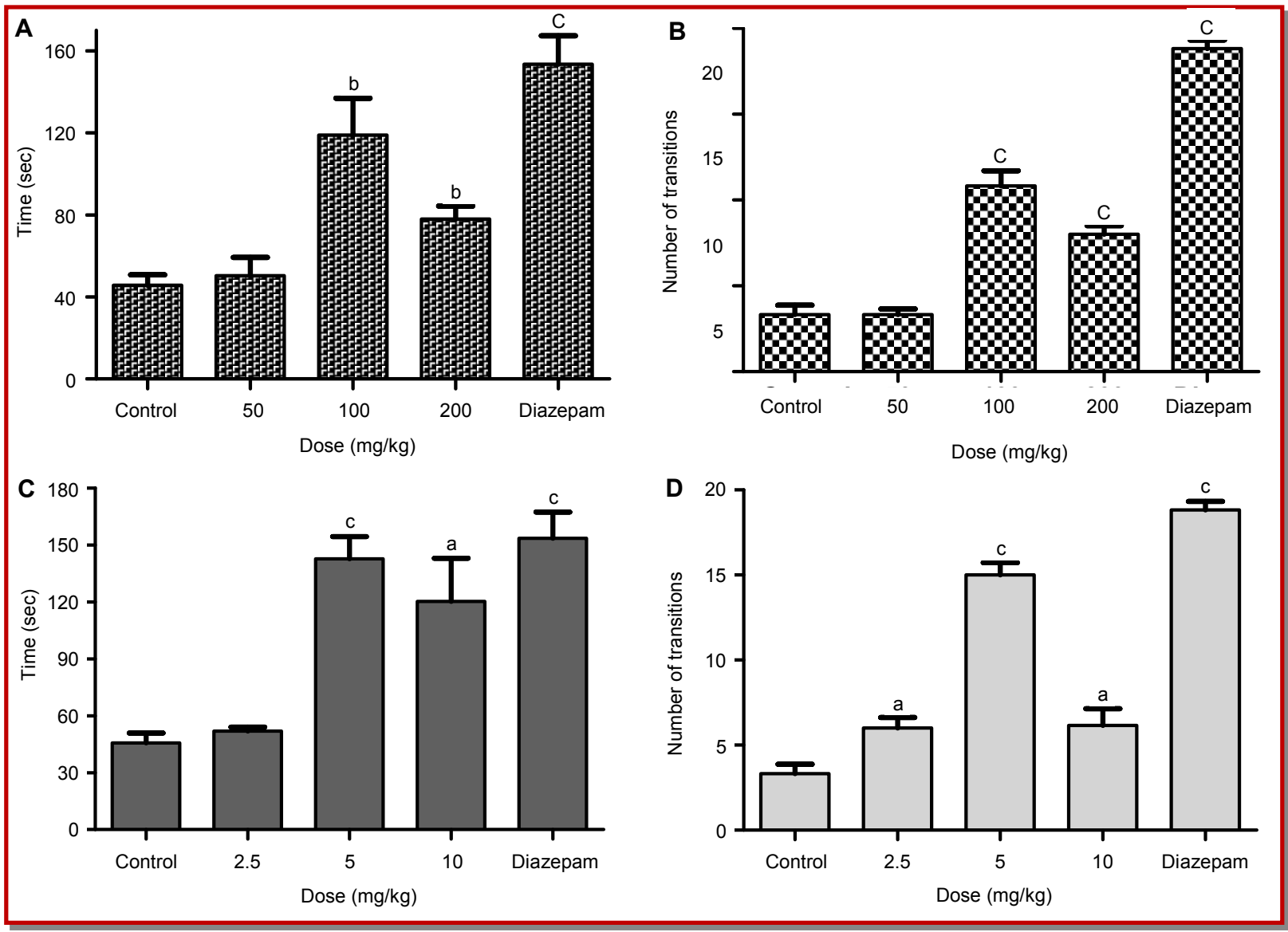

Figure 3: Effect of crude extract and n-hexane fraction of C. annuum at test doses in Light and dark model. Time spent on illuminated side (A), No of Transitions (B) for crude extract and Time spent on illuminated side (C), No of Transitions (D) for n-hexane fraction. Control (Saline and tween 80 2.5\%), 50,100,200 mg/ kg (crude extract of C. annuum), 2.5, 5,10 mg/ kg (n-hexane fraction of $C$. annuum) and Diazepam $1 \mathrm{mg}$. All values are expressed as mean $\pm \mathrm{SEM}, \mathrm{n}=6 .{ }^{*}: \mathrm{P}<0.05,{ }^{* *}: \mathrm{P}<0.01,{ }^{* * *}: \mathrm{P}<0.001$

like through benzodiazepine receptor (Silva and Brandao, 2000; Walf and Frye, 2007). In this study, it was observed that the crude extract and hexane fraction produced anxiolytic like effect at the dose of 100 and 5 $\mathrm{mg} / \mathrm{kg}$ respectively in EPM. It significantly increased the time spent in open arms as well as the entry to the open arms. At these doses, it significantly decreased the time spent in the close arms. In the light and dark model, the hexane fraction at $5 \mathrm{mg} / \mathrm{kg}$ elicited almost the same effect as the standard diazepam. It significantly increased the time spent in the illuminated side of the model and also enhanced the number of transitions to the illuminated side.

Traction test was used to determine the muscle relaxant activity of the extract and in comparison, with the standard diazepam. The $n$-hexane fraction at a high dose of $10 \mathrm{mg} / \mathrm{kg}$ increase the reestablishment time significantly. The mice failed to put the hind paw on the wire within $5 \mathrm{sec}$ which reflects the strong muscle relaxant property the crude extract at a high dose of 200 $\mathrm{mg} / \mathrm{kg}$ also displayed a significant muscle relaxant activity.
The centrally acting effect of the extract was indicated because the latency time was reduced and the duration of sleep was prolonged. The hexane fraction at $10 \mathrm{mg} /$ $\mathrm{kg}$ shows almost the same effect as diazepam. The crude extract at a high dose of $200 \mathrm{mg} / \mathrm{kg}$ showed significant sedative and hypnotic activity while at a lower dose of 50 and $100 \mathrm{mg} / \mathrm{kg}$, the results were almost same as for the control.

Diazepam evoked the anxiolytic, muscle relaxant and sedative like effects by impairing the action of $\mathrm{GABA}_{\mathrm{A}}$ (Yemitan and Salahdeen, 2005; Rauf et al., 2013). Binding of diazepam to the gamma sub-unit of the $G_{A B A}$ receptor results in the modification of their structure due to which the activity of $\mathrm{GABA}_{\mathrm{A}}$ receptor increases. Which increases the frequency of channel opening as the frequency increase it ultimately results in an increased chloride ion conductance and inhibition of the action potential (Ali et al., 2008; Mahendran et al., 2014). This may explain the underlying mechanism of action for our tested extracts, because the overall expression was similar to diazepam. Anxiolytic, sedative and muscle relaxant like effects of diazepam are in 


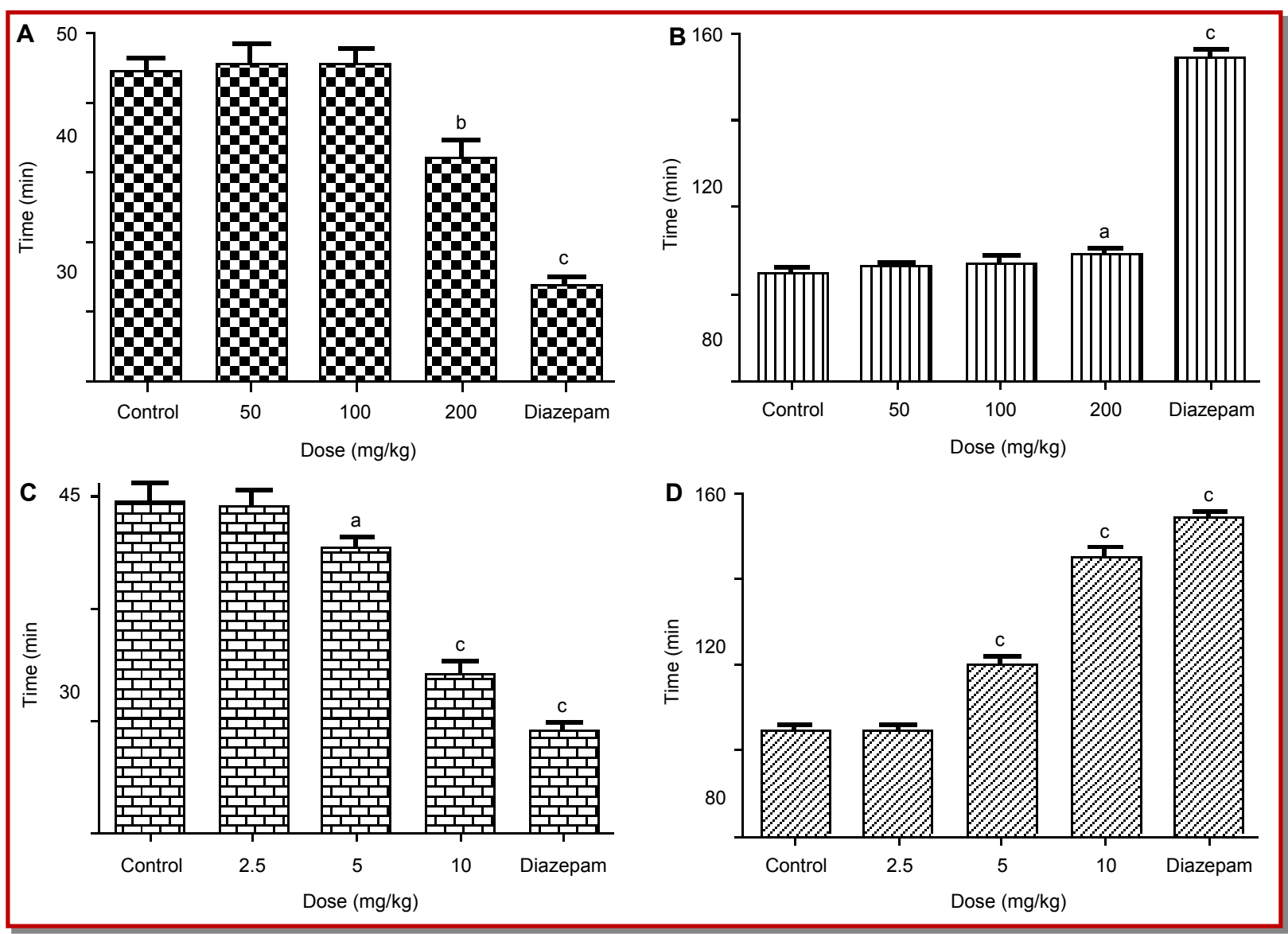

Figure 4: Effect of crude extract and $n$-hexane fraction of $C$. annuum at test doses in thiopental induced sleep in mice. onset time of sleep (A), duration of sleep (B) for crude extract and onset time of sleep (C), duration of sleep (D) for n-hexane fraction. Control (Saline and tween 80 2.5\%), 50,100,200 mg/ $\mathrm{kg}$ (crude extract of C. annuum), 2.5,5,10 mg/ $\mathrm{kg}$ ( $n$-hexane fraction of $C$. annuum), and Diazepam $1 \mathrm{mg}$. All values are expressed as mean $\pm \mathrm{SEM}, \mathrm{n}=6$., ${ }^{\mathrm{a}} \mathrm{p}<0.05,{ }^{\mathrm{b}} \mathrm{p}<0.01,{ }^{\mathrm{c}} \mathrm{p}<0.001$

ascending order of dose. Our extract showed similar behavior, so $C$. annuum extract might be worked through GABA which is similar to diazepam.

C. annuum is reported to be an excellent source of polyphenols, particularly flavonoids such as quercetin, myricetin, luteolin, and capsaicin (Lee and Villalon, 1995; Miean and Mohamed, 2001; Chen and Hwa, 2013), caffeic, coumaric and 3,4-dimethoxy cinnamic acid glucosides (Mattila and Hellstorm, 2007). In addition to that in pepper leaves some other flavonoides were also identified, apigenin and its analogue apigenin 7piofuranosyl [ $1 \rightarrow 2$ ] glucopyrano-side (Choi et al., 2007) and the previous data on these constituents suggest their anxiolytic and antidepressant activity (Lister, 1987, Crupi et al., 2013, Impellizzeri et al., 2013). So, the anxiolytics and sedative like effects may be due to these compounds. Hexane fraction is so potent because the HPLC analysis of it shows that this fraction contains most abundantly the three major compounds qurecetin, luteolin and kamperol which have been already reported for its anxiolytic like effect.

\section{Conclusion}

The crude methanolic extract $(100 \mathrm{mg} / \mathrm{kg})$ and $n$ hexane fraction $(5,10 \mathrm{mg} / \mathrm{kg})$ of $C$. annuum possess strong muscle relaxant and anxiolytic like activity while the $n$-hexane fraction at a dose $10 \mathrm{mg} / \mathrm{kg}$ possesses strong sedative like activity. Therefore, this C. annuum may possibly be considered for the treatment of anxiety and related neuropsychiatric disorders by conducting further pharmacological studies and mechanism of sedative and anxiolytic like action.

\section{Ethical Issue}

The study was approved by the ethical committee of Department of Pharmacy, University of Peshawar.

\section{Conflict of Interest}

The authors declare that there is no conflict of interest. 


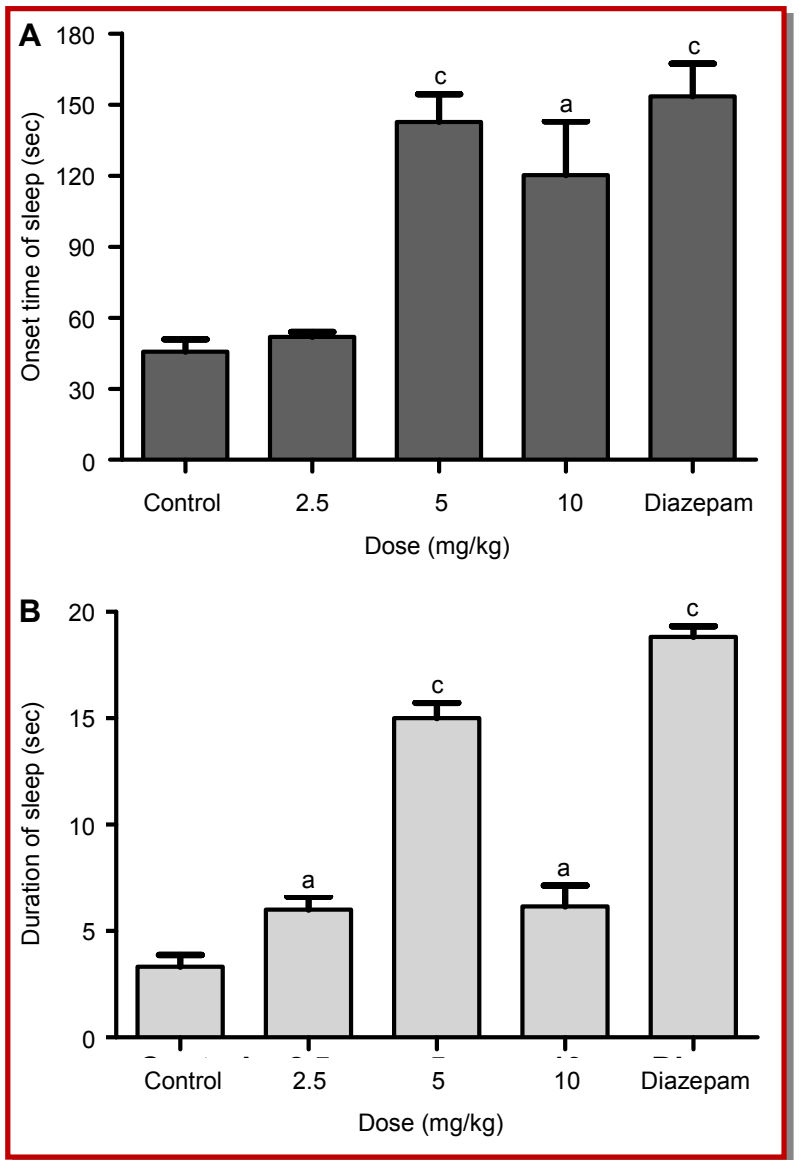

Figure 5: Effect of $n$-hexane fraction of C. annum at test doses in thiopental induced sleep in mice. Onset time of sleep (A), duration of sleep (B). Control (Saline and Tween 80 2.5\%), 2.5,5,10 $\mathrm{mg} / \mathrm{kg}$ (n-hexane fraction of C. annum), and diazepam $1 \mathrm{mg}$. All values are expressed as mean \pm SEM; $n=6$; ${ }^{a} p<0.05,{ }^{b} p<0.01$, $c p<0.001$

\section{Acknowledgement}

We are thankful to NIH Islamabad, Pakistan for providing experimental animals on payment.

\section{References}

Aguirre-Hernandez E, Gonzalez-Trujano ME, Martanez AL, Moreno J, Kite G, Terrazas T, Soto-Hernaidez M. HPLC/MS analysis and anxiolytic-like effect of quercetin and kaempferol flavonoids from Tilia americana var. mexicana. J Ethnopharmacol. 2010; 127: 91-97.

Ali A, Rao NV, Shalam M, Gouda TS, Babu J, Shantakumar S. Anxiolytic activity of seed extract of Caesalpinia bonducella (Roxb.) in laboratory animals. Int J Pharmacol. 2008; 5.

Chen LK, Hwa Y. Anti-inflammatory and anti-oxidant activities of red pepper (Capsicum annuum L.) stalk extracts comparison of pericarp and placenta extracts. J Functional Foods. 2013; 5: 1724-31.

Choi J, Hur J, Cho H, Park. Phenolic compounds from Capsi- cum annuиm leaves showing radical scavenging effect. Korean J Pharmacogn. 2007; 38: 258-62.

Chouinard G. Issues in the clinical use of benzodiazepines: Potency, withdrawal, and rebound. J Clin Psychiat. 2004; 65: 7-12.

Crawley J, Goodwin FK. Preliminary report of a simple animal behavior model for the anxiolytic effects of benzodiazepines. Pharmacol Biochem Behav. 1980; 13: 167-70.

Crupi R, Paterniti I, Ahmad I, Campolo M, Esposito E, Cuzzocrea S. Effects of palmitoylethanolamide and luteolin in an animal model of anxiety/depression. CNS Neurol Disord Drug Targets. 2013; 12: 989-1001.

Dandiya PC. Studies on Acorus calamus (III): Some pharmacological actions of the volatile oil. J Pharmacol Exp Ther. 1959; 125: 353-59.

El-Ashmawy IM, Bayad AE, Omar AME. Antidepressant activity of a polyherbal mixture in mice. Int Food Res J. 2014; 21: 2273-77.

Ferrari CKB, Torres EAFS. Biochemical pharmacology of functional foods and prevention of chronic diseases of aging. Biomed Pharmacotherap. 2003; 57: 251-60.

Gupta V, Wankhede S, Deshmukh V, Juvekar A. Anxiolytic effect of Couroupita guianensis aubl. flower extracts in mice. Int J Pharm BioSci. 2013; 4: 420-26.

Harborne J, Williams C. Advances in flavonoid research since 1992. Phytochemistry 2000; 55: 481-504.

He D, Zhang P, Luo X, Li X, Wang L, Li S, Xu Y. Evaluation of the anxiolytic and antidepressant activities of the aqueous extract from Camellia euphlebia Merr. ex Sealy in mice. Evid Based Complement Alternat Med. 2015; 2015.

Hellian-Ibarrola MC, Ibarrola DA, Montalbetti Y, Kennedy ML, Heinichen O, Campuzano M, Tortoriello J, Fernandez S, Wasowski C, Marder M, De Lima TCM, Mora S. The anxiolytic-like effects of Aloysia polystachya (Griseb.) Moldenke (Verbenaceae) in mice. J Ethnopharmacol. 2006; 105: 400-08.

Hollman PK. Dietary flavonoids: Intake, health effects and bioavailability. Food Chem Toxicol. 1999; 37: 937-42.

Impellizzeri D, Esposito E, Di Paola R, Ahmad A, Campolo M, Peli A, Morittu VM, Britti D, Cuzzocrea S. Palmitoylethanolamide and luteolin ameliorate development of arthritis caused by injection of collagen type II in mice. Arthritis Res Therap. 2013; 15: R192.

Ishisaka MK, Yamauchi K, Tsuruma M, Shimazawa K, Tsuruta $\mathrm{M}$, Hara A, Hideaki. Luteolin shows an antidepressantlike effect via suppressing endoplasmic reticulum stress. Biol Pharm Bull. 2011; 34: 1481-86.

Johnson W. Final report on the safety assessment of Capsicum annuum extract, Capsicum annuum fruit extract, Capsicum annuum resin, Capsicum annuum fruit powder, Capsicum frutescens fruit, Capsicum frutescens fruit extract, Capsicum frutescens resin, and capsaicin. Int J Toxicol. 2007; 26: 3-106.

Khan H, Saeed M, Gilani AUH, Khan MA, Dar A, Khan I. The antinociceptive activity of Polygonatum verticillatum rhizomes in pain models. J Ethnopharmacol. 2010; 127: 521-27.

Kim WK, Kang EO, Oidovsambuu K, Jung S, Kim SH, Nho BS, 
Um CW, Hun B. Anti-oxidant activity of phenolics in leaves of three red pepper (Capsicum annuum) cultivars. J Agric Food Chem. 2014; 62: 850-59.

Komaki AN, Shahidi Z, Sarihi S, Salehi A, Ghaderi I. Anxiolytic effects of acute injection of hydro-alcoholic extract of lettuce in the elevated plus-maze task in rats. Avicenna J Neuro Psych Physio. 2014; 1: 86-95.

Kumar S, Sharma A. Apigenin: The anxiolytic constituent of Turnera aphrodisiaca Ward. Pharm Biol. 2006; 44: 84-90.

Lader M, Morton S. Benzodiazepine problems. Br J Addict. 1991; 86: 823-28.

Lee YH, Villalon LR. Flavonoids and anti-oxidant activity of fresh pepper (capsicum annuum) cultivars. J Food Sci. 1995; 60: 473-76.

Lister R. The use of a plus-maze to measure anxiety in the mouse. Psychopharmacology 1987; 92: 180-85.

Mahendran G, Thamotharan G, Sengottuvelu S, Bai VN. Evaluation of anticonvulsant, sedative, anxiolytic, and phytochemical profile of the methanol extract from the aerial parts of Swertia corymbosa (Griseb.) Wight ex CB Clarke. Bio Med Res Int. 2014; 2014.

Mansouri MS, Naghizadeh M, Farbood B, Mashak Y, Sarkaki A, Alireza. A possible mechanism for the anxiolytic-like effect of gallic acid in the rat elevated plus maze. Pharmacol Biochem Behav. 2014; 117: 40-46.

Mattila PH, Hellstorm J. Phenolic acids in potatoes, vegetables, and some of their products. J Food Comp Anal. 2007; 20: 15260.

Miean KH, Mohamed S. Flavonoid (myricetin, quercetin, kaempferol, luteolin, and apigenin) content of edible tropical plants. J Agric Food Chem. 2001; 49: 3106-12.
Muhammad N, Saeed M, Khan H, Haq I. Evaluation of $n$ hexane extract of Viola betonicifolia for its neuropharmacological properties. J Nat Med. 2013; 67: 1-8.

Nogueira EV, Silvia V. Methodological evaluation of the elevated plus-maze (EPM) test for anxiety in rats. J Biomed Sci. 1996; 17: 47-54.

Pellow S, File SE. Anxiolytic and anxiogenic drug effects on exploratory activity in an elevated plus-maze: A novel test of anxiety in the rat. Pharmacol Biochem Behav. 1986; 24: 52529.

Rauf A, Ali J, Khan H, Mubarak SM, Patel S. Emerging CAM Ziziphus nummularia with in vivo sedative-hypnotic, antipyretic and analgesic attributes. 3Biotech 2016; 6: 11-20.

Rauf A, Muhammad N, Barkatullah KA. Antinociceptive, sedative and muscle relaxants activity of Caralluma tuberculata NE Brown. Orthop Muscul Syst. 2013; 2: 2.

Silva RCB, Brandao ML. Acute and chronic effects of gepirone and fluoxetine in rats tested in the elevated plus-maze: An ethological analysis. Pharm Biochem Behav. 2000; 65: 209-16.

Tiwari P, Verma R, Ahirwar D, Chandy A, Dwivedi S. Evaluation of anxiolytic effect of Syzygium aromaticum: A traditional herb of India. Asian Pac J Trop Dis. 2014; 4: S7780

Walf AA, Frye CA. The use of the elevated plus maze as an assay of anxiety-related behavior in rodents. Nat Protocols. 2007; 2: 322-28.

Wesolowska A, Jadczak D, Grzeszczuk M. Chemical composition of the pepper fruit extracts of hot cultivars Capsicum annuит L. Acta Sci Pol Hortorum Cultus. 2011; 10: 171-84.

Yemitan $\mathrm{O}$, Salahdeen. Neurosedative and muscle relaxant activities of aqueous extract of Bryophyllum pinnatum. Fitoterapia 2005; 76: 187-93. 